\title{
Islamic Ethics and the COVID-19 Pandemic: A Report on an Interdisciplinary 2020 Summer School
}

\author{
Khalid Elzamzamy \\ Institute of Living/Hartford Healthcare, Hartford, Connecticut, USA \\ kh.zamzamy@gmail.com
}

\begin{abstract}
The coviD-19 pandemic has touched every aspect of human life and posed a myriad of ethical questions. In an attempt to equip graduate students with the necessary tools to explore the pandemic-related questions from an Islamic perspective, a summer school titled "Islamic Ethics and the Covid-19 Pandemic" was co-organized by the Center for Islamic Legislation and Ethics, Qatar and the Leuven Centre for the Study of Islam and Society, Belgium from 9 to 12 August, 2020. The purpose of this report is to provide an overview of topics discussed during the school and to highlight a plethora of references which may be consulted for more information on the topic.
\end{abstract}

\section{Keywords}

Islam - ethics - COVID-19 - Coronavirus - Islamic ethics 


\section{الأخلاق الإسلامية وجائة كوفيد-19: تقرير حول مدروسة صيفية متعددة التخصصات في عام 2020

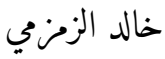 مستشفى هارتفورد، ولاية كونيتيكت، الولايات المتحدة الأمريكية}

\section{الخلاصة}

لقد أثرت جائحة كوفيد-19 على جميع جوانب الحياة اليومية وأثارت العديد من المعضلات الأخلاقية.

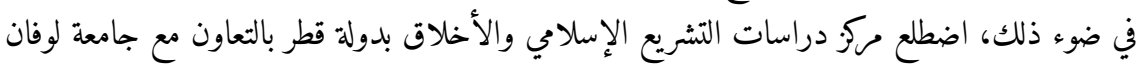

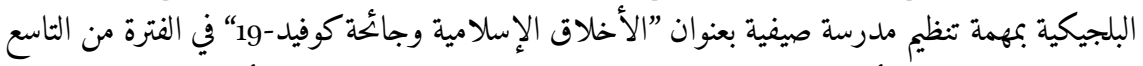

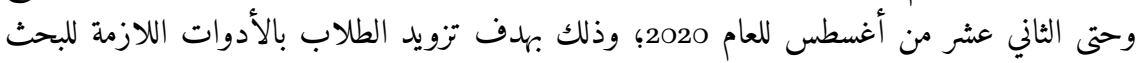

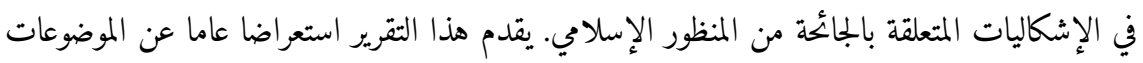

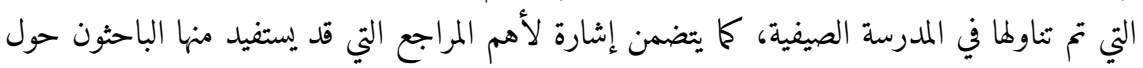
هذا الموضوع.

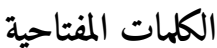

الإسلام - الأخلاق - كوفيد-19 - فيروس كورونا - الأخلاق الإسلامية

\section{Introduction}

The COVID-19 pandemic has touched every aspect of human life and posed a myriad of ethical questions. Similar to the ongoing debates among the medical community about all aspects of the virus, religious communities have also been dealing with ongoing questions and challenges at the intersection of the pandemic and their spiritual beliefs, ritual practices, and moral principles.

In an attempt to provide graduate students who are interested in religion and health with the necessary tools to explore the pandemic-related questions from an Islamic perspective, the Center for Islamic Legislation and Ethics (CILE), Qatar (www.cilecenter.org/), along with the Leuven Centre for the Study of Islam and Society (LCSICS), Belgium (https://ghum.kuleu ven.be/lcsics/home), co-organized the first of its kind summer school titled "Islamic Ethics and the Covid-19 Pandemic" which was held virtually from 9 to 

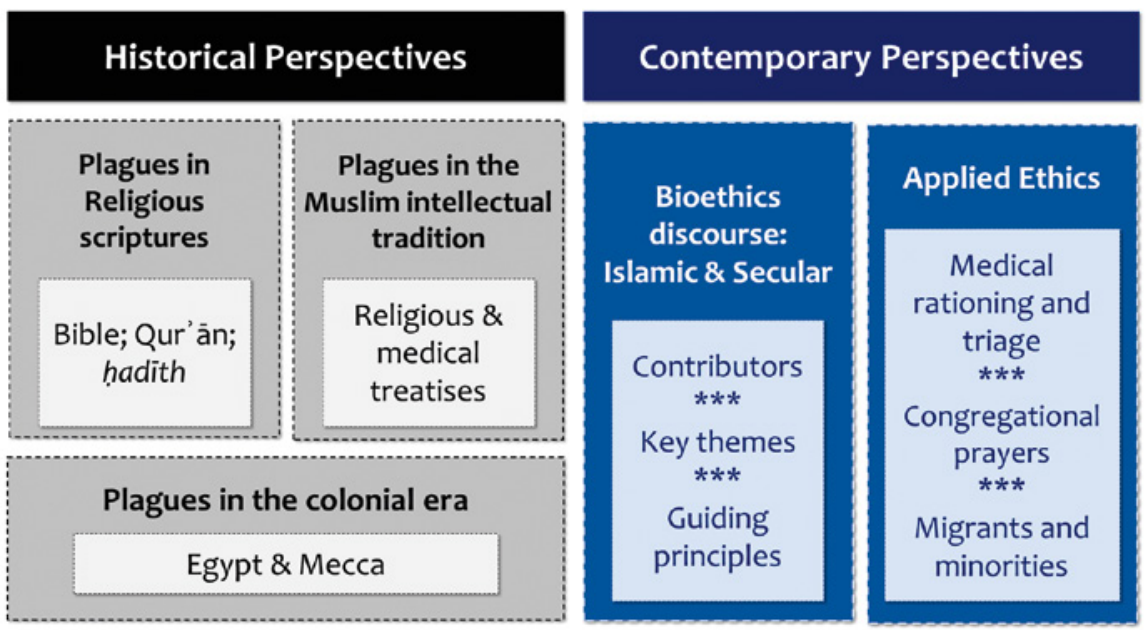

FIGURE 1 An overview of the summer school

12 August 2020. The summer school was attended by 5 o students from all over the world. It included around 18 hours of lectures and discussions facilitated by six faculty members from both institutes. Through an interdisciplinary approach, the summer school provided the students with a historical overview of the medical understanding and ethical discussions on early plagues. In addition, the school addressed various ethical approaches and discourses on cOVID-19, including applied practical case examples.

The purpose of this report is to provide an overview of the lectures presented during the summer school (see fig. 1). The reading material used during the program will be cited and referenced in this report when appropriate.

\section{Contemporary Perspectives}

\subsection{Surveying the Religious and Secular Bioethics Field}

Mohammed Ghaly (Hamad Bin Khalifa University (HBKU), Qatar) provided a comprehensive outlook on the major contributors and themes dominating the bioethics field on COVID-19 both from Islamic as well as secular spheres. Students were engaged in an exercise surveying their views on the most important bioethical issues they encountered during the pandemic.

The major contributions to the field of Islamic bioethics and COVID-19 can be found in academic journals and books, communications by fatwa institutions, websites, and courses. Some Islamic academic journals dedicated (or are dedicating) special issues to COVID-19 such as the Journal of Islamic 
Ethics (by Brill), various journals of Qatar University, and the Journal of Sharia and Islamic Studies by Kuwait University. Some academic books collected the fatwās (religious verdicts) issued by scholars on CoviD-19 while other books focused on the rulings on specific rituals such as congregational prayers (Yusrī 2020; Sabrī 2020). Fatwā institutes play a role that is comparable to the role of bioethics institutes in addressing large scale issues - the main difference, however, is that many fatwa institutions are not independent bodies, but state governed, which could raise questions about objectivity. Several transnational institutes have been actively issuing statements and fatwās since the beginning of the pandemic, including the International Islamic Fiqh Academy (IIFA), the International Association of Muslim Scholars (IAMS), the European Council for Fatwa and Research (ECFR), the Assembly of Muslim Jurists of America (AMJA), along with national fatwā committees in various Muslim countries, including Egypt, Saudi Arabia, Algeria, and others. Some news and opinion websites, such as aljazeera.net and atharah.com also published on CoviD-19related ethical questions.

On the other hand, the secular discourse on bioethics has been disseminated by scholarly journals, bioethics and academic institutes, newspapers, and courses. The New England Journal of Medicine, The Lancet, Nature, and Science have published high impact papers and were concerned with both scientific and ethical issues. Bioethics institutes have also been contributing to the discussion, including the UK Nuffield Council (nuffieldbioethics .org), the Hastings Center (thehastingscenter.org), the Berman Institute of Bioethics, bioethics.net (maintained by the editorial staff of The American Journal of Bioethics), the Center for Bioethics \& Human Dignity (bioethics. com). Various newspapers posted actively on the topic such as the New York Times and Foreign Policy. Training modules on ethics and covid-19 have been offered by academic institutes such as the University of Melbourne (https://mdhs-study.unimelb.edu.au/short-courses/mms-short-courses/ clinical-ethics-and-covid-19/overview) and Harvard Medical School (https:// curriculum.covidstudentresponse.org/).

The key issues addressed in the Islamic discourse include ritual prayers, fasting, zakāt (almsgiving), pilgrimage, burial rituals, resource allocation, and issues related to the role of states and governments. On the other hand, the secular discourse focused on resource-allocation and prioritization, lockdown ethics, ethics of public health surveillance, healthcare workers' rights and obligations, research ethics, human rights, food ethics, as well as the duty and role of governments.

Ghaly highlighted some of the gaps in both the Islamic and secular fields. Despite the significance and impact of religious beliefs on health behaviors, 
the religious perspective seemed to be largely absent in the secular sphere, and - whenever addressed - it seemed to be largely negatively stereotyped. In contrast, the engagement of the religious discourse with scientific data has been suboptimal. The religious discourse seems to have not engaged with some critical questions such as those pertaining to research ethics, human rights, and the duties of the government towards their citizens.

Mutaz al-Khatib (н в KU, Qatar), in his lecture, offered some guiding ethical principles in the context of a pandemic. Discussions and debates took place among students on the clinical, ethical, and political nature of some of the rising issues as well as various ethical approaches to answer the pandemicrelated challenges. The lecturer offered a set of ethical principles, moral values as well as four frameworks through which ethical questions may be addressed namely, public health ethics, medical ethics, normative ethics, and virtue ethics (Beauchamp 2016).

From among the myriad of key applied issues mentioned above, the summer school faculty chose a few to elaborate on, each in a separate lecture. These issues included:

1) Congregational prayers.

2) Medical rationing and triage.

3) Dilemmas of migrants and minorities.

The following section will offer a glimpse of each of these topics.

\subsubsection{Congregational Prayers}

Rulings on congregational prayers were identified as one of the most debated topics during the pandemic. Individual scholars as well as national and transnational Islamic institutions contributed to the debate. These individuals and institutions can be divided into two main groups: one supporting the lockdown of mosques and the ban on congregational prayers, and the other opposing the lockdown while advocating for observing precautionary measures during congregational prayers (WHO 202O). The scientific and religious arguments, as well as the solutions proposed by each group, were presented in the lecture (Ghaly 202ob; Yusrī 2020).

\subsubsection{Medical Rationing and Triage}

Rationing health resources during the pandemic has been one of the critical topics both in Islamic and in secular bioethical writings. The key question posed by Mutaz al-Khatib in his lecture was "how can medical resources be allocated fairly during the CoviD-19 pandemic, and who should be treated first?" He emphasized the need for an interdisciplinary approach to tackle such questions. Al-Khatib surveyed two secular and two Islamic existing 
frameworks on the "medical rationing" question. The participating students engaged in an analytical discussion of each framework, analyzing its underlying values, criteria, and recommendations. The lecturer concluded by offering his own framework and explained its underlying values and criteria (Truog, Mitchell and Daley 2020). The four frameworks which were explored in this lecture were those proposed by:

a. The British Medical Association (Hurford 2020).

b. The New England Journal of Medicine (Emanuel et al. 2020).

c. The European Council for Fatwa and Research (ECFR 2O2O)

d. The Assembly of Muslim Jurists of America (AMJA 2020).

\subsubsection{Dilemmas of Migrants and Minorities}

Ray Jureidini (HBKU, Qatar) presented a social perspective on COVID-19 highlighting the role of the pandemic in bringing to light or even worsening existing healthcare disparities for minorities. The lecture also underlined the major economic and health impact of the pandemic on refugees and forced migrants as well as migrant and domestic workers globally (OHCH R 202O). The impact on domestic violence and human trafficking was also underlined. The lecture referred to contributions from scholarly journals, United Nations institutions, international human rights organizations, as well as newspapers and $\mathrm{TV}$ documentaries. The Islamic perspective on this matter and data from various Muslim countries were briefly discussed.

\section{$3 \quad$ Historical Perspectives}

The summer school offered a rich historical glimpse, from plagues in the Old Testament to plagues in Egypt and in Mecca during hajj (pilgrimage) seasons in the 13th/19th century. The historical account provided a context for the ethical discussions on plagues by exploring various scriptural, spiritual, mystical, medical, rational, social, economic, and geo-political contributing factors.

Samer Rashwani (HBKU, Qatar) offered an overview of plagues in religious scriptures including the Old Testament, Qurān, and hadìth collections. The Old Testament, the Qurān, and hadith collections contain references to plagues that afflicted the Egyptians and the Israelites. In these scriptural references, plagues were generally depicted as a means of punishment and at times as a sign of God's mercy. Scriptures admonish to turn to God when faced with plagues and afflictions. 
Moving on from the scriptures, Rashwani provided insights on how early Muslims (the Prophet's Companions) engaged with the scriptures and debated about the interpretation and best of course of action in the face of plagues and epidemics. Their approaches highlighted a process of ijtihäd (ethical and legal reasoning) attempting to understand the plague phenomenon and to formulate a response to it. At times, their interpretations resulted in different opinions.

The Islamic intellectual heritage built upon this foundation of scriptural references and early Muslim debates on the topic. Samer Rashwani, Mohammed Ghaly, and Arjan Post (LCSICs, Belgium) in their respective lectures highlighted the rich theological, mystical, rational, and medical debates and approaches by Muslim scholars in various regions during several epidemics.

Mohammed Ghaly underlined the interdisciplinary polymathic nature of Muslim scholars' engagement with the topic of plagues. The Muslim medical discourse, pioneered by Abū Bakr al-Razī (d. 320/932), Ibn Sīnā (Avicenna, d. 428/1037), and Ibn al-Nafis (d. 687/1288), was influenced by the Greek tradition, offering four explanations of plagues including miasmatic, natural, astrological, and contagion causation theories. Muslim religious scholars, such as Ibn Qayyim al-Jawziyya (d. 751/1350), Ibn Ḥajar al-Asqalānī (d. 852/1448), and Mar'ì b. Yūsuf al-Karmī (d. 1033/1624) engaged with the medical discourse of the time, accepting or refuting some of its claims (al-Karmī 2018; Ibn Qayyim 1957; Ibn Ḥajar 1991). In addition, Muslim physicians, such as Lisān al-Dīn Ibn al-Khațīb (d. 776/1374) and Abū Jaffar Ibn Khātima (d. 770/1369) defended the medical understanding of contagion and the ensuing sanitary recommendations demonstrating a strong grasp of the religious literature (Ghaly 2020a; Ḥasan 2013; Ibn al-Khațīb 2015).

Samer Rashwani highlighted how early Muslim scholars were mainly concerned with the theological aspects of the tradition concerning plagues. However, later theologians developed more nuanced and sophisticated approaches that attempted to reconcile between divergent views and offer practical guidance.

Arjan Post, in his lecture, explored two other dimensions in the Islamic tradition concerning plagues and epidemics vis-à-vis God's will on earth. First, a theological approach attempting to understand the causes of diseases and the role of medical cures as a means to eliminate them. This was the approach of the "traditionalists" (mostly Hanbalī scholars). Second, a mystical dimension of Sufi ascetics emphasizing the importance of relying on God and the connection with Him in eliminating diseases (Curry 2017). 
Finally, in two lectures rich with historical photographs, Amr Ryad (LCSICS, Belgium) offered a socio-geo-political dimension of plagues in the Muslim world through two prominent episodes. The first was the episode of Egypt's plagues in the 12th/18th and 13 th/19th centuries and the different responses of the political forces of the time, including the French and the Ottomans. The interaction between medical experts and religious scholars with the political powers of the time was highlighted (Fahmy 2018). The second was the episode of the plagues during the haij (pilgrimage) season in Mecca and the role of various colonial political powers in regulating and surveilling the hajj season for sanitary (medical) as well as security (anti-radicalism) reasons (Low 2008).

\section{$4 \quad$ Conclusion}

The summer program was highly appreciated by the students according to both their verbal and written feedback. The students acknowledged the interdisciplinary approach as one of the main strengths of the school. The historical perspective was found to be intriguing and enlightening. Despite minor technical challenges, both faculty and students acknowledged that the online platform has resulted in a greater reach and a wider impact for the summer school. The summer school will be followed by a semester-long course on "Islamic Ethics of Pandemics" which will be part of the Master's degree program in Applied Islamic Ethics offered by the College of Islamic Studies, Hamad Bin Khalifa University, Qatar.

\section{Bibliography}

AMJA Resident Fatwa Committee. 2020. "Scarcity of Medical Resources and Rationing during the COVID-19 Pandemic." Assembly of Muslim Jurists of America: www.amjaonline.org/fatwa/en/87747/scarcity-of-medical-resources-and -rationing-during-the-covid-19-pandemic.

Beauchamp, Tom L. 2016. "The Principles of Biomedical Ethics as Universal Principles." In Islamic Perspectives on the Principles of Biomedical Ethics, edited by Mohammed Ghaly, 91-119. London: World Scientific Publishing.

Curry, John J. 2017. “Scholars, Sufis, and Disease: Can Muslim Religious Works Offer Us Novel Insights on Plagues and Epidemics among the Medieval and Early Modern Ottomans?" In Plague and Contagion in the Islamic Mediterranean, edited by Nükhet Varlık, 27-56. Newark: ARC Humanities Press. 
ECFR (European Council for Fatwa and Research). 2020. "Al-Bayān al-Khitāmī lilDawra al-Ṭāri’a al-Thalāthīn lil-Majlis al-Ūrūbbī lil-Iftā’ wa-l-Buhūth al-Mun'aqida bi-Tiqniyyat Zoom al-Tawāșuliyya [Final declaration of the 3oth emergency session of the European Council for Fatwa and Research conducted via Zoom]." Al-Majlis al-Ūrūbbì lil-Iftä' wa-l-Buhūth: www.e-cfr.org/blog/2020/o4/o1/.

Emanuel, Ezekiel J., Govind Persad, Ross Upshur, Beatriz Thome, Michael Parker, Aaron Glickman, Cathy Zhang, Connor Boyle, Maxwell Smith, and James P. Phillips. 2020. "Fair Allocation of Scarce Medical Resources in the Time of Covid-19." The New England Journal of Medicine 382: 2049-2055. Doi: 10.1056/NEJMsb2005114.

Fahmy, Khaled. 2018. In Quest of Justice: Islamic Law and Forensic Medicine in Modern Egypt. Oakland: University of California Press.

Ghaly, Mohammed. 2020a. "Religious Rituals During the Coronavirus Pandemic: Insights from Islamic Bioethics." Bioethics.net: www.bioethics.net/2020/o4/religious -rituals-during-the-coronavirus-pandemic-insights-from-islamic/.

Ghaly, Mohammed. 202ob. "Religion During the Coronavirus Pandemic: Islamic Bioethical Perspectives." The Hastings Center: www.thehastingscenter.org/religion -during-the-coronavirus-pandemic-islamic-bioethical-perspectives/.

Hasan, Muḥammad. 2013. Thalāth Rasāil Andalusiya fì l-Ṭāūn al-jārif (749Hj/1348M) [Three Andalusian Treatises on the Sweeping Plague (749 A.H./1348 C.E.)]. Tunis: Bayt al-Hikma.

Hurford, James. E. 2020. "The BMA COVID-19 Ethical Guidance: A Legal Analysis." The New Bioethics, 26(2): 176-189. Doi: 10.1080/20502877.2020.1762027.

Ibn Hajar al-'Asqalānī. 1991. Badhl al-Mā'ūn fí Faḍl al-Tāèun [On the Virtues of the Plague]. Riyad: Dār al-‘̄sṣima.

Ibn al-Khațīb, Lisān al-Dīn. 2015. Muqni'āt al-Sāil 'an al-Marad al-Hāìl [Convincing the Questioner Regarding the Appalling Illness], edited by Hayāt Qārra. Rabat: Dār al-Amān.

Ibn al-Qayyim al-Jawziyya. 1957. Al-Tibb al-Nabaw̄̄ [Prophetic Medicine], edited by 'Abd al-Ghanī 'Abd al-Khāliq. Beirut: Dār al-Fikr.

al-Karmī, Mar`̄i b. Yūsuf. 2018. Tahqqūq al-Zunūn bi-Akhbār al-Tāāūn [Bringing Certainty about the Plague]. Istanbul: Dār al-Lubāb.

Low, Michael C. 2008. "Empire and the Hajj: Pilgrims, Plagues, and Pan-Islam under British Surveillance, 1865-1908." International Journal of Middle East Studies 40(2): 269-29o. Doi: 10.1017/So020743808080549.

онснR (Office of the High Commissioner for Human Rights). 2020. "Covid-19 and Minority Rights: Overview and Promising Practices." United Nations: www.ohchr .org/Documents/Issues/Minorities/OHCHRGuidance_COVID19_MinoritiesRights .pdf.

Șabrī, Mas'ūd. 2020. Fatāwā l-'Ulamā’ Hawl Vīrūs Kūrūnā [Corona Virus-Related Religious Verdicts by Scholars]. Cairo: Dār al-Bashīr. 
Truog, Robert D., Christine Mitchell, and George Q. Daley. 2020. "The Toughest Triage Allocating Ventilators in a Pandemic." New England Journal of Medicine 382: 19731975. Doi: 10.1056/NEJMp2005689.

wно (World Health Organization). 2020. "Practical Considerations and Recommendations for Religious Leaders and Faith-Based Communities in the Context of COVID-19." World Health Organization: www.who.int/publications/i/item/ practical-considerations-and-recommendations-for-religious-leaders-and-faith -based-communities-in-the-context-of-covid-19.

Yusrī, Muhammad. 2020.Nāzilat Ta'țīl al-Masājid fíl-Quțr al-Wāhid [The Contemporary Dilemma of Mosque National Lockdowns]. Cairo: Dār al-Yusr. 